\title{
Penerapan Model Pembelajaran Group Investigation (gi) untuk Meningkatkan Keterampilan Berpikir Kritis Siswa pada Materi Gerak Lurus Kelas X
}

\author{
Nadiya $^{1)}$, Haris Rosdianto ${ }^{2)}$, dan Eka Murdani ${ }^{3)}$ \\ 1) Prodi Pendidikan Fisika STKIP Singkawang \\ E-mail: nadiya114@yahoo.com \\ 2) Prodi Pendidikan Fisika STKIP Singkawang \\ E-mail: harisrosdianto@yahoo.com \\ 3) Prodi Pendidikan Fisika STKIP Singkawang \\ E-mail: ekamurdani@gmail.com
}

\begin{abstract}
Abstrak. Penelitian ini bertujuan untuk mendapatkan gambaran peningkatan keterampilan berpikir kritis dan respon siswa terhadap model pembelajaran group investigation pada materi gerak lurus.Jenis penelitian ini merupakan penelitian kuantitatif. Sampel diambil dengan teknik purposive sampling yang berjumlah 28 orang siswa di salah satu Madrasah Aliyah di kota Singkawang. Bentuk tes yang digunakan berupa tes uraian.Hasil penelitian ini adalah deskriptif kuantitatif dari keterampilan berpikir kritis siswa pada materi gerak lurus.Kategori keterampilan berpikir kritis siswa menggunakan kategori N-gain.Hasil penelitian menunjukkan bahwa indikator menyimpulkan dengan skor sebesar 0,65 dengan kategori sedang, indikator penyelidikan dengan skor sebesar 0,48 dengan kategori sedang, indikator menganalisis dengan skor sebesar 0,52 dengan kategori sedang, indikator pemecahan masalah dengan skor sebesar 0,48 dengan kategori sedang dan indikator membuat keputusan dengan skor sebesar 0,67 dengan kategori sedang. Rata-rata persentase keseluruhan dari angket respon siswa terhadap keterampilan berpikir kritis siswa sebesar 83,6\% dengan kategori positif. Hasil analisis data menunjukkan bahwa keterampilan berpikir kritis siswa setiap indikator berkategori sedang. Hasil penelitian ini bisa menjadi referensi bagi peneliti lain untuk meningkatkan keterampilan berpikir kritis siswa pada indikator menyimpulkan, penyelidikan, menganalisis, pemecahan masalah dan membuat keputusan.
\end{abstract}

Kata Kunci: Model Group Investigation, Keterampilan Berpikir Kritis, Gerak Lurus

\section{Pendahuluan}

Fisika merupakan salah satu cabang ilmu pengetahuan alam yang terdiri dari kumpulan pengetahuan (produk), cara berpikir, bekerja (sikap) dan cara untuk melakukan penyelidikan yang bersifat ilmiah yang kajiannya terbatas dalam dunia nyata dan bertujuan untuk memberi pemahaman terhadap gejala-gejala alam yang ada di sekitarnya [1]. Dalam proses pembelajaran fisika guru masih cenderung menggunakan pembelajaran satu diantaranya yaitu pembelajaran bersifat informatif [2]. Proses pembelajaran seperti ini membuat siswa menjadi lebih pasif dan malas untuk berpikir. Akibatnya, siswa tidak mempunyai rasa ingin tahu yang kuat dan tidak memiliki keterampilan untuk mengkomunikasikan ide-ide baru maupun keterampilan berpikir untuk memecahkan permasalahan.

Berpikir kritis adalah sebuah proses yang terarah dan jelas yang digunakan dalam kegiatan mental seperti memecahkan masalah, mengambil keputusan, membujuk, menganalisis asumsi, dan melakukan penelitian ilmiah [1]. Proses mental tersebut untuk menganalisis atau mengevaluasi informasi. Informasi tersebut bisa didapatkan dari hasil pengamatan, pengalaman, akal sehat atau komunikasi, yaitu kemampuan untuk berpendapat dengan cara terorganisasi dan juga kemampuan untuk mengevaluasi secara terarah pendapat pribadi dan pendapat orang lain [3]. Keterampilan berpikir kritis penting diajarkan di sekolah karena keterampilan berpikir diperlukan oleh siswa untuk memecahkan masalah dalam kehidupannya. 


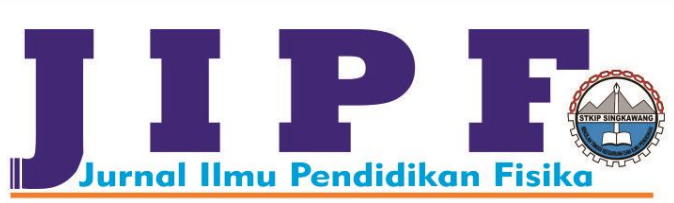

Kenyataan yang terjadi selama ini, guru kurang memperhatikan penggunaan model pembelajaran dengan penerapan kompetensi dasar yang sesuai. Penggunaan model pembelajaran yang tidak sesuai dapat menyebabkan siswa malas untuk berpikir menyelesaikan suatu permasalahan dalam pembelajaran yang berlangsung, sehingga keterampilan berpikir kritis siswa menjadi tidak berkembang [4].

Permasalahan tersebut harus diselesaikan, agar keterampilan berpikir kritis siswa dapat dikembangkan.Salah satu solusi yang dapat digunakan untuk menyelesaikan permasalahan tersebut adalah dengan memilih salah satu model pembelajaran yang tepat sebagai salah satu upaya dalam meningkatkan keterampilan berpikir kritis siswa.Model pembelajaran yang efektif untuk mengatasi kesulitan belajar siswa dalam keterampilan berpikir kritis yaitu dengan mengimplementasikan suatu pembelajaran yang berpusat pada siswa di mana siswa diajak untuk lebih aktif dalam mempresentasikan atau mengkomunikasikan pemahamannya melalui model Group Investigation (GI). GI merupakan suatu model pembelajaran dengan membentuk kelompok kecil, siswa dituntut untuk berpartisipasi secara aktif dalam kelompok untuk mencari sendiri informasi yang berkaitan dengan materi pembelajaran.Penelitian ini bertujuan untuk menggambarkan keterampilan berpikir kritis siswa pada indikator menyimpulkan, penyelidikan, menganalisis, pemecahan masalah dan membuat keputusan pada materi gerak lurus.

\section{METODE}

Penelitian ini adalah penelitian deskriptif kuantitatif yang diarahkan untuk menggambarkan keterampilan berpikir kritis siswa pada indikator menyimpulkan, penyelidikan, menganalisis, pemecahan masalah dan membuat keputusan pada pembelajaran fisika materi gerak lurus. Populasi dalam penelitian ini adalah seluruh siswa kelas X di salah satu Madrasah Aliyah di kota Singkawang. Teknik pengambilan sampel menggunakan teknik purposive sampling yang berjumlah 28 siswa.Instrumen pengumpulan data yang digunakan dalam penelitian ini adalah tes keterampilan berpikir kritis berupa tes uraian.Tes terdiri dari tiga indikator keterampilan berpikir kritis, yaitu indikator menyimpulkan, pemecahan masalah dan membuat keputusan.

\section{HASIL DAN PEMBAHASAN}

All Adapun kategori peningkatan keterampilan berpikir kritis siswa pada materi gerak lurus menggunakan kategori $\mathrm{N}$-gain sebagai berikut.

TABLE I

KATEGORI PENINGKATAN KETERAMPILAN BERPIKIR KRITIS BERDASARKAN N-GAIN [5]

\begin{tabular}{cc}
\hline Skor $\boldsymbol{N \text { -gain }}$ & Kategori \\
\hline$g>\geq 0,7$ & Tinggi \\
$0,3 \leq \quad$ Sedang \\
$<g><0,3$ & Rendah
\end{tabular}

Tabel.1 menyatakan kategori peningkatan keterampilan berpikir kritis siswa. Berikut ini data hasil keterampilan berpikir kritis siswa pada indikator menyimpulkan, penyelidikan, menganalisis, pemecahan masalah dan membuat keputusan.

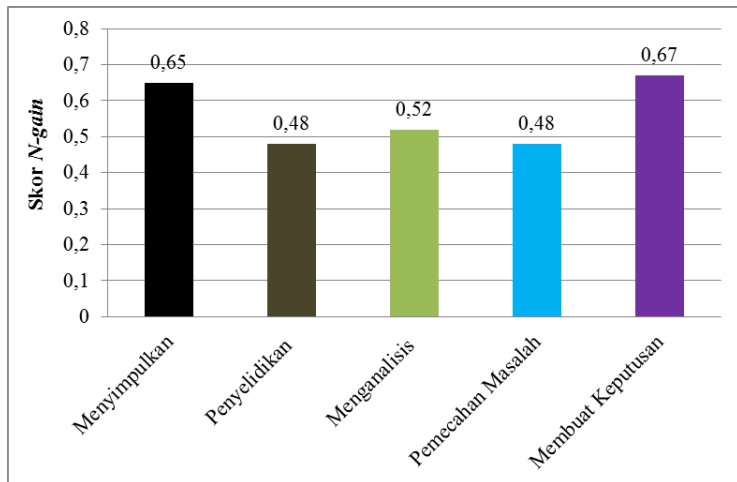

Gambar. 1 Data hasil keterampilan berpikir kritis siswa pada materi gerak lurus

Berdasarkan Gambar. 1 tampak bahwa skor untuk kelima indikator keterampilan berpikir kritis diperoleh hasil yang berbeda-beda.Pada indikator menyimpulkan dengan skor $\mathrm{N}$-gain sebesar 0,65 dengan kategori sedang, indikator penyelidikan dengan skor $\mathrm{N}$-gain sebesar 0,48 dengan kategori sedang, indikator menganalisis dengan skor $\mathrm{N}$-gain sebesar 0,52 dengan kategori sedang, indikator pemecahan masalah dengan skor $\mathrm{N}$-gain sebesar 0,48 dengan kategori sedang dan indikator membuat keputusan dengan skor $\mathrm{N}$-gain sebesar 0,67 dengan kategori sedang. 


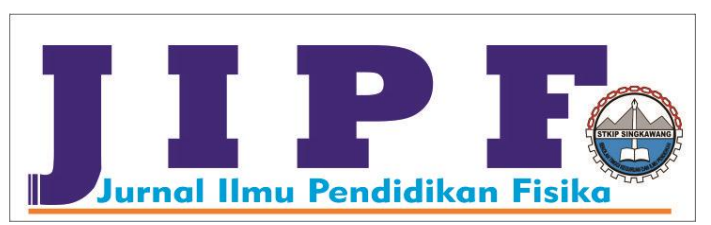

TABEL 2

HASIL ANALISIS DATA ANGKET RESPON SISWATIAP INDIKATOR KETERAMPILAN BERPIKIR KRITIS

\begin{tabular}{clc}
\hline No & \multicolumn{1}{c}{$\begin{array}{c}\text { Indikator Keterampilan Berpikir } \\
\text { Kritis }\end{array}$} & $\mathbf{( \% )}$ \\
\hline 1 & Menyimpulkan & 86 \\
2 & Penyelidikan & 68 \\
3 & Menganalisis & 82 \\
4 & Pemecahan Masalah & 89 \\
5 & Membuat Keputusan & 93 \\
Rata-rata & 83,6 \\
\hline
\end{tabular}

Berdasarkan Tabel.2 persentase keterampilan berpikir kritis siswa pada indikator menyimpulkan sebesar $86 \%$, persentase keterampilan berpikir kritis siswa pada indikator penyelidikan sebesar $68 \%$, persentase keterampilan berpikir kritis siswa pada indikator menganalisis sebesar $82 \%$, persentase keterampilan berpikir kritis siswa pada indikator pemecahan masalah sebesar $89 \%$, persentase keterampilan berpikir kritis siswa pada indikator membuat keputusan sebesar 93\%. Rata-rata persentase keseluruhan dari angket respon siswa terhadap keterampilan berpikir kritis siswa sebesar 83,6\% dengan kategori positif.

\section{KESIMPULAN DAN SARAN}

Berdasarkan hasil analisis data dan pembahasan yang dilakukan dapat disimpulkan penerapan model pembelajaran group investigation yang diterapkan pada siswa dapat menggambarkan peningkatan keterampilan berpikir kritis siswa pada indikator menyimpulkan sebesar 0,65 dengan kategori sedang, penyelidikan sebesar 0,48 dengan kategori sedang, menganalisis sebesar 0,52 dengan kategori sedang, pemecahan masalah sebesar 0,48 dengan kategori sedang dan membuat keputusan sebesar 0,67 dengan kategori sedang. Respon siswa terhadap indikator keterampilan berpikir kritis memiliki persentase $83,6 \%$ dengan kategori positif. Diharapkan dari hasil penelitian ini dapat dijadikan referensi untuk penelitian selanjutnya agar dapat meningkatkan keterampilan berpikir kritis siswa.

\section{DAFTAR PUSTAKA}

[1] Dewi, Mitra Rahmawati., Sriyono., dan Ashari. 2014.”Analisis Keterampilan Berpikir Kritis Siswa pada Pembelajaran Fisika dengan Pendekatan Starter Eksperimen".Radiasi Vol. 5. No. 1 (2014).

[2] Suryadana, Brian Aziz., Suprihati, Tjiptaning., dan Astutik, Sri. 2012 "Penerapan Mosel Kooperatif Tipe Group Investigation (GI) disertai Media Kartu Masalah Pada Pembelajaran Fisika Di SMA". Jurnal Pembelajaran Fisika, Universitas Jember. Vol. 1 No. 3 (2012).

[3] Rahayu, Endang puji. 2014. Peningkatan Kemampuan Berpikir Kritis Matematis Melalui Model Pembelajaran Kooperatif Tipe Group Investigation Siswa Kelas IV SD Negeri Suka Maju 3 Depok, Skripsi, Program Studi Pendidikan Guru Madrasah Ibtidaiyah. Universitas Islam Negeri Syarif Didayatullah: Jakarta.

[4] Afcariono, Muhammad. 2008. "Penerapan Pembelajaran Berbasis Masalah untuk Meningkatkan Kemampuan Berpikir Kritis Siswa pada Mata Pelajaran Biologi”. Jurnal Pendidikan Inovatif Vol. 3 No. 2 (2008).

[5] Hake, Richard R. 1999.“Analyzing Change/Gain Scores”.Dept. Of Physics Indian Tersedia: www.physics.indiana.edu/ sdi/Analyzing Change-Gain.pdf. (diakses tanggal 21 September 2015) 